\title{
Urological tumors treatment in Brazil during the SARS-Cov-2 outbrake
}

\author{
Luciano A. Favorito ${ }^{1,2}$ \\ ${ }^{1}$ Unidade de Pesquisa Urogenital - Universidade do Estado de Rio de Janeiro - Uerj, Rio de Janeiro, RJ, \\ Brasil, ${ }^{2}$ Serviço de Urologia, Hospital Federal da Lagoa, Rio de Janeiro, RJ, Brasil
}

\section{COMMENT}

SARS-CoV-2 pandemic has a great impact in all medical fields and the paper of Anjos Silva and Collegues from Brazil (1) shows interesting data about surgery in patients with urological tumors. Previous studies shows that SARS-CoV-2 changes the urologic practice in several fields (2-5), but the treatment of urological tumors during the outbreak has specially importance (6-8).

In this interesting paper the authors studied if uro-oncological surgeries at pandemic are safe in a cohort of 213 patients (161 patients were submitted to elective surgery and 44 to emergency surgery) in a reference hospital in Brazil and concluded that Elective uro-oncological procedures at the COVID-19 epidemic period in a COVID-19-free Institute are safe, and patients who need urgent procedures, with a long period of hospitalization, need special care to avoid COVID-19 infection and its outcomes.

We would like to congratulate the authors by the interesting and important report in this paper.

\section{CONFLICT OF INTEREST}

None declared.

\section{REFERENCES}

1. Silva GCDA, Abe DK, Pedrenho R Neto, Vilares RN, Cordeiro MD, Coelho RF, et al. Evaluation of urooncological surgical treatment during the Sars-CoV-2 pandemic in a Brazilian tertiary oncology institution, the new world epicenter. Int Braz J Urol. 2021;47:378-85.

2. Lauxmann MA, Santucci NE, Autrán-Gómez AM. The SARS-CoV-2 Coronavirus and the COVID-19 Outbreak. Int Braz J Urol. 2020;46(suppl.1):6-18.
3. Chen W, Wang XM, Fu GQ, Fu GQ, Zeng X, Wu CP, et al. Special strategies and management of urological diseases during the COVID-19 pandemic: initial experiences from a Medical Center of China. Int Braz J Urol. 2020;46(suppl.1):19-25.

4. Esperto F, Papalia R, Autrán-Gómez AM, Scarpa RM. COVID-19's Impact on Italian Urology. Int Braz J Urol. 2020;46(suppl.1):26-33. 
5. Sanchez LR, Cathelineau X, Pinto AMA, Borque-Fernando Á, Gil MJ, Yee CH, et al. Clinical and Surgical Assistance in Prostate Cancer during the COVID-19 Pandemic: Implementation of assistance protocols. Int Braz J Urol. 2020;46(suppl.1):50-61.

6. Zequi SC, Abreu D. Consideration in the management of renal cell carcinoma during the COVID-19 Pandemic. Int Braz J Urol. 2020;46(suppl.1):69-78.
7. Casco NC, Carmona MJ, Soto ÁJ. Therapeutic and Surgical Indications for Patients with Penile Cancer in the COVID-19 era. Int Braz J Urol. 2020;46(suppl.1):86-92.

8. Zampolli HC, Rodriguez AR. Laparoscopic and Robotic Urology Surgery during Global Pandemic COVID19. Int Braz J Urol. 2020;46(suppl.1):215-21.

\section{Luciano A. Favorito, MD, PhD}

Unidade de Pesquisa Urogenital

da Universidade do Estado de Rio de Janeiro - UERJ,

Rio de Janeiro, RJ, Brasil

E-mail: lufavorito@yahoo.com.br
ARTICLE INFO

Luciano A. Favorito http://orcid.org/0000-0003-1562-6068

Int Braz J Urol. 2021; 47: 386-7
Submitted for publication: October 22, 2020

Accepted:

November 01, 2020 